\title{
Influence of naloxone infusion on quality and duration of analgesia produced by thoracic epidural morphine and bupivacaine
}

\author{
SD Gupta ${ }^{1 *}$, A Pareek ${ }^{2}, S$ Maji $^{3}$, S Bhar Kundu ${ }^{4}, M$ Ray $^{5}$ \\ Associate Professor ${ }^{1}$, Consultant Anaesthetist ${ }^{2}$, Assistant Professor ${ }^{4}$, Department of Anaesthesiology, \\ Postgraduate Institute of Medical Education and Research, Kolkata, India. Consultant Anaesthtist ${ }^{3}$, \\ Department of Anaesthesiology, Midnapur Medical College, Midnapur, West Bengal, India. Principal ${ }^{5}$, \\ Burdwan Medical College, Burdwan, West Bengal, India.
}

*Corresponding author: $\underline{\text { sdg_1603@yahoo.co.in }}$

\begin{abstract}
Introduction
Controlled trials in children and adolescents have shown that, small-dose naloxone infusions $(0.25 \mu \mathrm{g} / \mathrm{kg} / \mathrm{hour})$ can significantly reduce opioid induced side effects without affecting opioid-induced analgesia.
\end{abstract}

\begin{abstract}
Material and methods
84 elective thoracotomy patients having combined thoracic epidural and general anesthesia for thoracotomy surgeries were randomly assigned to one of the two study groups. All patients of Group A $(n=42)$ received continuous intravenous infusion of naloxone at a calculated dose of $0.25 \mu \mathrm{gkg}^{-1} \mathrm{hr}^{-1}$ and patients of Group B $(\mathrm{n}=42)$ received continuous intravenous infusion of normal saline at a fixed rate. All patients were premedicated with fentanyl $1 \mu \mathrm{g} / \mathrm{kg}$ i.v. After placement of epidural catheter at $\mathrm{T}_{6-8}$ interspaces, all patients were administered morphine $0.1 \mathrm{mg} / \mathrm{kg}$ with $0.125 \%$ bupivacaine immediately before induction of general anaesthesia. VAS was assessed immediately after extubation and a bolus dose of $0.01 \mathrm{mg} / \mathrm{kg}$ epidural morphine was administered when VAS exceeded 3 in postoperative follow up period of $72 \mathrm{hrs}$ in all patients. We measured the incidence of side effects like vomiting, nausea, pruritus and respiratory depression and number of times rescue analgesic was required.
\end{abstract}

\begin{abstract}
Results
Small dose naloxone infusion significantly reduced the opioid induced side effects without antagonizing opioid induced analgesia.

Conclusion

Naloxone reduces epidural morphine-induced side effects without significant alteration of its analgesic effects.
\end{abstract}

Keywords: thoracic epidural; post-operative analgesia; morphine; naloxone

\section{Introduction}

Modern philosophy of pain management for trauma and surgery must provide more than mere humanitarian success to the distressed patient. A system for relieving pain not only must prove its positive influence on the processes of recovery but also should be measurable both in terms of patient satisfaction, improved function and progressive effects on healing. Pain management must be prophylactic, integral to surgery and proactive rather than reactive. Lung volume reduction surgery is a good modern example of a procedure to which these above principles apply. There is experimental evidence of thoracic epidural analgesia (TEA) having a demonstrable superiority over other analgesic techniques in terms of effects on pulmonary function, stress reduction, myocardial function, $\mathrm{O}_{2}$ delivery, and reduction of myocardial irritability, particularly when epidural techniques are used 
intra-operatively and extended to cover the postoperative period. Advent of neuraxial opioids provides the impetus to add TEA to the armamentarium of thoracic anaesthesiology and establish it as the gold standard. ${ }^{1}$

In patients of all ages, opioids are the cornerstone of management of moderate to severe pain. ${ }^{2}$ The unique feature of opioids given epidurally for analgesia is the lack of sensory, sympathetic or motor block, which allows the patients to ambulate without the risk of orthostatic hypotension or motor incoordination. ${ }^{3}$ Regardless of the method of administration, all opioids produce unwanted side effects, as pruritus, nausea-vomiting, constipation, urinary retention, cognitive impairment, tolerance and dependence. ${ }^{4}$

Preclinical in vivo and in vitro studies demonstrate that direct competitive antagonism of Gs-coupled excitatory opioid receptor functions by the administration of extremely low doses of clinically available opioid antagonist, markedly enhances the opioid's analgesic potency and simultaneously attenuates opioid tolerance and dependence. ${ }^{5}$ Controlled trials in children and adolescents show that small-dose naloxone infusions $(0.25 \mu \mathrm{g} / \mathrm{kg} /$ hour $)$ can significantly reduce opioid-induced side effects without affecting analgesia. ${ }^{6}$

Another study shows that low dose naloxone $(0.25 \mu \mathrm{g} / \mathrm{kg} /$ hour $)$ significantly reduces the patient controlled analgesia (PCA) cumulative morphine consumption during the first 24 hours postoperatively and incidence of postoperative nausea and vomiting (PONV) and pruritus were also significantly reduced. Patients receiving a higher dose of naloxone $(1 \mu \mathrm{g} / \mathrm{kg} /$ hour $)$ experience a reduction in PONV and pruritus but consume similar amounts of morphine compared with patients in the placebo group. ${ }^{7}$
Based on these previous studies, we hypothesize that a small dose naloxone infusion $(0.25 \mu \mathrm{g} / \mathrm{kg} / \mathrm{hr})$, when administered prophylactically as an intravenous infusion, could prevent the most common undesired side effects of opioid administration (pruritus, nausea and vomiting) in thoracotomy patients receiving epidural morphine for post operative pain management.

Aims of this study is to compare the duration of effective analgesia and alertness between the two groups and to compare the incidence of any untoward effects like pruritus, vomiting and respiratory depression.

\section{Material and Methods}

After obtaining institutional ethical committee approval and informed patient consent, this prospective, randomized, double blind, controlled study was conducted.

84 adult patients of ASA physical status II, of both sexes, age group between 18 and 35 years, scheduled for elective thoracotomy under general anaesthesia, were recruited by an investigator before surgery and the study protocol was instituted from the immediate to $72 \mathrm{hrs}$ postoperative period.

Sample size was calculated based on the study of Lynn G. Maxwell, Sandra C. Kaufmann, Sally Bitzer et $\mathrm{al}^{6}$, on the basis of incidence of pruritus. With assumption that the incidence of pruritus in the control group would be $60 \%$, 42 subjects were required per group to detect a reduction by $30 \%$ in this incidence with $80 \%$ power and 5\% probability of type-1 error.

Exclusion criteria:

- Unwilling patients

- Contraindication to epidural catheter placement

- Those not extubated after surgery

- Those who were unable to communicate after recovery from anaesthesia

- Those requiring concomitant 
benzodiazepine administration

- Patients with known history of allergy to study drugs

- $\quad$ Those who received opioids within 7 days of the study

No patients received any premedication and they were randomly assigned to two study groups, Group A $(n=42)$ and Group B $(n=42)$ through a computer-generated random number. Intravenous infusion of lactated Ringer's solution was started in the operating room and midazolam $0.02-0.03 \mathrm{mg} / \mathrm{kg}$ and fentanyl $1 \mu \mathrm{g} / \mathrm{kg}$ was given intravenously. Then intravenous infusion of diluted naloxone at a calculated dose of $0.25 \mu \mathrm{g} / \mathrm{kg} / \mathrm{hr}$ in Group A patients and intravenous normal saline infusion of same volume at a fixed rate in Group B patients were started.

Standard monitoring with electrocardiogram (ECG), pulse oximetry, and automated blood pressure was applied and monitored at 5-min intervals.

Prior to induction of general anaesthesia, epidural puncture was done in thoracic region between T6 and T8 with a 18G Tuohy epidural needle using the loss of resistance technique and the catheter was inserted $3-5 \mathrm{~cm}$ into the epidural space. $3 \mathrm{ml}$ of lidocaine $2 \%$ with 1:200,000 adrenaline was administered through epidural catheter to confirm placement.

Before establishment of general anaesthesia, each patient was administered a bolus dose of morphine $0.1 \mathrm{mg} / \mathrm{kg}$ with bupivacaine $0.125 \%$ into the epidural catheter with a total volume of $0.15 \mathrm{ml} / \mathrm{kg}^{8}$

After pre-oxygenation, patients were induced with intravenous thiopentone $5 \mathrm{mg} / \mathrm{kg}$, or till the loss of eyelash reflex. Tracheal intubation was facilitated after achieving full relaxation with vecuronium $0.1 \mathrm{mg} / \mathrm{kg}$ i.v. Maintenance of anaesthesia was done with halothane $(0.25 \%-0.75 \%)$ in $\mathrm{O}_{2}$ along with supplemental doses of vecuronium.

At the end of surgery, anaesthetic agents were discontinued and neuromuscular blockade was reversed with $50 \mu \mathrm{g} / \mathrm{kg}$ neostigmine along with $10 \mu \mathrm{g} / \mathrm{kg}$ glycopyrrolate. Patients were extubated after fulfilling the criteria for extubation.

Patients complaining of pain immediately after termination of general anaesthesia, were offered systemic opioids with fentanyl $1 \mu \mathrm{g} / \mathrm{kg}$ intravenously and excluded from the study.

Patients were administered the first top up dose for the epidural morphine as soon as Visual Analogue Scale ${ }^{9}$ score exceeded 4 and the time was noted. All patients received top up epidural morphine along with local anaesthetics to maintain postoperative analgesia for $72 \mathrm{hrs}$. The time interval between the activation of the epidural morphine and the first top up dose was regarded as the effective duration of analgesia in minutes. Systolic, diastolic and mean blood pressures were measured non-invasively and heart rate was monitored at 5 minute intervals throughout the $72 \mathrm{hr}$ postoperative period.

Incidence of untoward events like vomiting, nausea, pruritus and respiratory depression were noted for the first $72 \mathrm{hrs}$ postoperatively and assessed using the evaluation scores noted in Table $1 .^{10}$

The assessment was carried out by other anesthesiologists who had not been involved in care of the patients and who were blinded to the group assignment.

Rescue medication was administered following the incidences of untoward events. 
Table 1: Scoring system of postoperative checkpoints $^{10}$

\section{Nausea/Vomiting}

$1:$ no nausea

2 : complains of nausea, but tolerable

3 : severe nausea, needs medication

Pruritus. (itching)

1: no itching.

2: complains of itching, but tolerable

3: severe itching, needs medication

\section{Alertness}

1: clear mentality

2: good response to verbal commands, but drowsy

3: poor response to repeated verbal commands

\section{Respiratory depression}

1: none detected

2: exist $(\mathrm{RR}<8$ min-1)

Statistical analysis was done by Microsoft Excel 97 (Microsoft Corporation, USA, 198596) and PS and Sample Size Calculations version 2.1.30. All data were entered into a MS excel spreadsheet and analyzed. Normally distributed numerical data (e.g. age, sex distribution, body weight) were analyzed using the Students t-test. The effects of the treatment were evaluated at each point using the Mann-Whitney $U$ test. The incidence of PONV was compared using Fischer's exact test. All tests were 2 tailed and $\mathrm{P}$ value $<0.05$ was considered statistically significant.

\section{Results}

Demographic profile (age, sex, weight) and haemodynamic parameters were comparable between the groups. Incidence of nausea and vomiting was significantly more in Group B. $38 \%$ patients had severe nausea and needed ondansetron as an antiemetic (Table 2). Pruritus was significantly less in Group A as compared to Group B (Table 3). Incidence of post-operative sedation was less in Group A as compared to Group B (Table 4). Duration of analgesia was more in Group A, but was statistically not significant (Table 5).

Table 2 Incidence of post-operative nauseavomiting (\%)

\begin{tabular}{|l|l|l|l|}
\hline & $\begin{array}{l}\text { Group A } \\
(n=42) \\
\text { Number of } \\
\text { patients (\%) }\end{array}$ & $\begin{array}{l}\text { Group B } \\
(n=42) \\
\text { Number of } \\
\text { patients (\%) }\end{array}$ & $\begin{array}{l}\text { P } \\
\text { value }\end{array}$ \\
\hline 1 : No nausea & $27(64.3 \%)$ & $12(28 \%)$ & $<0.05$ \\
\hline $\begin{array}{l}\text { 2: Complains of nausea, } \\
\text { but tolerable }\end{array}$ & $11(25 \%)$ & $14(33 \%)$ & $<0.05$ \\
\hline $\begin{array}{l}3 \text { : Severe nausea, } \\
\text { needed medication }\end{array}$ & $4(9.5 \%)$ & $16(38 \%)$ & $<0.05$ \\
\hline
\end{tabular}

Table 3 Incidence of pruritus (itching) (\%).

\begin{tabular}{|l|l|l|l|}
\hline & $\begin{array}{l}\text { Group A } \\
(n=42) \\
\text { Number of } \\
\text { patients (\%) }\end{array}$ & $\begin{array}{l}\text { Group B } \\
(n=42) \\
\text { Number of } \\
\text { patients (\%) }\end{array}$ & $\begin{array}{l}\text { P } \\
\text { value }\end{array}$ \\
\hline 1 : No itching & $25(59 \%)$ & 0 & $<0.05$ \\
\hline $\begin{array}{l}2 \text { :Complain itching, } \\
\text { but tolerable }\end{array}$ & $16(38 \%)$ & $27(64 \%)$ & $<0.05$ \\
\hline $\begin{array}{l}3: \text { Severe itching, } \\
\text { needed medication }\end{array}$ & $1(2.3 \%)$ & $15(33 \%)$ & $<0.05$ \\
\hline
\end{tabular}

Table 4 Incidence of post-operative sedation (\%)

\begin{tabular}{|l|l|l|l|}
\hline & $\begin{array}{l}\text { Group A } \\
(n=42) \\
\text { Number of } \\
\text { patients (\%) }\end{array}$ & $\begin{array}{l}\text { Group B } \\
(n=42) \\
\text { Number of } \\
\text { patients (\%) }\end{array}$ & $\begin{array}{l}P \\
\text { value. }\end{array}$ \\
\hline 1 : Clear mentality & $38(90 \%)$ & $30(71 \%)$ & $<0.05$ \\
\hline $\begin{array}{l}2: \text { Good response } \\
\text { to verbal } \\
\text { command, but } \\
\text { drowsy }\end{array}$ & $4(9.5 \%)$ & $12(28 \%)$ & $<0.05$ \\
\hline $\begin{array}{l}3: \text { Poor response to } \\
\text { repeated verbal } \\
\text { command }\end{array}$ & 0 & 0 & $>0.05$ \\
\hline
\end{tabular}

Table 5 Duration of post-operative analgesia

\begin{tabular}{|l|l|l|l|}
\hline & $\begin{array}{l}\text { Group A } \\
(n=41) \\
\text { Mean } \pm \text { SD }\end{array}$ & $\begin{array}{l}\text { Group B } \\
(n=41) \\
\text { Mean } \pm \text { SD }\end{array}$ & $\begin{array}{c}P \\
\text { value }\end{array}$ \\
\hline $\begin{array}{l}\text { Duration of effective } \\
\text { analgesia (minutes) }\end{array}$ & $627.83+/-60$ & $609+/-74.52$ & $>0.05$ \\
\hline
\end{tabular}




\section{Discussion}

Intrathecal morphine, one of the hydrophilic opioids, is the first line therapy for many units and reportedly can be effective for more than 24 hrs. Opioid administration via an epidural route is one of the most rational and effective methods of control of post thoracotomy pain and is also regarded as the gold standard of pain management.

Reported incidence of complications of the use of neuraxial opioids showed respiratory depression $5-7 \%$ in subarachnoid block and $0.1-2 \%$ in epidural route, pruritus $60 \%$ in subarachnoid block and $1-100 \%$ in epidural route, nausea and vomiting $20-30 \%$ in subarachnoid block and epidural route, urinary retention 50\% in subarachnoid block and 15$25 \%$ in epidural route. ${ }^{11}$

In a study by Gan et $\mathrm{al}^{7}$ the incidence of PONV and pruritus were significantly reduced with the addition of low dose naloxone $(0.25 \mu \mathrm{g} / \mathrm{kg} / \mathrm{hr})$. In another study by Lynne $\mathrm{G}$ et $\mathrm{al}^{6}$ a reduction of opioid induced side effects with small doses of naloxone $(0.25 \mu \mathrm{g} / \mathrm{kg} / \mathrm{hr})$ infusion in children and adolescents was found. Similar findings have been demonstrated in our study, where the incidence of nausea and vomiting in the group receiving naloxone was approximately half of that in the group not receiving the antagonist drug. All patients of the latter group also experienced pruritus whereas it was reduced to $40 \%$ with addition of naloxone. Both differences were statistically significant.

Lynn $G$ et $\mathrm{al}^{6}$ did not demonstrate an adversely affected opioid induced analgesia with the addition of naloxone. Similarly in the study of Gan et $\mathrm{al}^{7}$ increasing the naloxone dose $(1 \mu \mathrm{g} / \mathrm{kg} / \mathrm{hr})$, did not increase the dose requirement of morphine and at the same time incidence of PONV and pruritus were decreased. Lower dose regimen $(0.25 \mu \mathrm{g} / \mathrm{kg} /$ hr) was associated with an enhancement of analgesic efficacy, indicated by reduction of PCA cumulative morphine consumption during the first post operative 24 hours. The proposed mechanism for this apparent paradoxical effect of naloxone is probably due to enhanced release of endogenous opioid and up regulation of opioid receptors. In our study the mean duration of effective analgesia was similar in both the groups and during the post operative 72 hours only two patients required thoracic epidural top up doses to maintain a VAS of less than four. Though we did not find an enhancement of analgesia, naloxone was not found to decrease the efficacy.

Additional findings included an increase in alertness score with naloxone and no respiratory depression in either group.

Effective pain relief is vital to the success of lung volume reduction surgeries and dictates the course of perioperative outcome. Considering the fact that thoracic epidural morphine has become the "Gold Standard" for pain relief, in spite of it producing several potential side effects, co-administration of low dose intravenous naloxone infusion may negate the undesired effects of morphine to reduce post-operative morbidity and mortality.

Intravenous administration of naloxone $(0.25 \mu \mathrm{g} / \mathrm{kg} / \mathrm{hr})$ can preserve opioid induced analgesia while minimizing itching, nausea, pruritus and somnolence. We are unable to state clearly, whether this is the ideal dose or whether higher doses might produce fewer side effects without interfering with analgesia. However it may be suggested that, clinicians should strongly consider starting a concomitant small dose naloxone infusion along with morphine in moderate to severe postoperative pain.

\section{References}

1. Conacher ID, Sunger PD. Pain management, Thoracic Anesthesia, Toel A Kaplan, Peter D Slung. 3rd ed, 436. 
2. Agency for Health Care Policy and Research. Clinical practice guidelines: acute pain management in infants, children and adolescents operative and medical procedures.

3. Rockville, MD: U.S. Department of Health and Human Services, 1992.

4. Conacher ID, Sunger PD. Pain management, Thoracic Anesthesia, Toel A Kaplan, Peter D Slung. 3rd ed, 208,

5. Yaster M, Kost-Byerly S, Maxwell LG. Opioid agonists and antagonists. In: Schechter NL, Berde $\mathrm{CB}$, Yaster M, eds. Pain in infants, children, and adolescents. Philadelphia: Lippincott Williams and Wilkins, 2003: 181-224.

6. Crain SM, Shen KF. Antagonist of excitatory opioid receptor function enhances morphine's analgesic potency and attenuate opioid tolerance / dependence liability. Pain 2000; 84: 121-31 http://dx.doi.org/10.1016/S0304-3959(99)00223-7

7. Maxwell LG, Sandra C. et al. The effects of a small-dose naloxone infusion on opioid-induced side effects and analgesia in children and adolescents treated with intravenous patientcontrolled analgesia: a double-blind, prospective, randomized, controlled study. Anesth. Analg. 2005; 100: 953-8. http://dx.doi.org/10.1213/01.ANE.0000148618.17736.3 C

PMid:15781505
8. Gan TJ, Ginsberg B, Glass PS et al. Opioid-sparing effects of a low-dose infusion of naloxone in patient - administered morphine sulfate. Anesthesiology1997;87:1075-81.

http://dx.doi.org/10.1097/00000542-199711000$\underline{00011}$ PMid:9366459

9. Morgan EG Jr, Mikhail MS, Murray MJ. Clinical Anesthesiology. Lange Medical Books/McGraw Hill. 4th Ed, 18.394-398.

10. Huskisson EC. Measurement of pain. Lancet 1974; 2: $1127-31$ http://dx.doi.org/10.1016/S0140-6736(74)90884-8

11. Choi JH, Lee J, Choi JH, Bishop MJ. Canadian Journal of Anesthesia. 2000;47:33-37 http://dx.doi.org/10.1007/BF03020728

PMid:10626715

12. Barash PG, Cullen BF, Stoelting RK. Handbook of Clinical Anaesthesia. Lippincot Williams and Wilkins. $5^{\text {th }}$ edition. pg 893. 